\title{
A survey of management practices that influence production and welfare of dairy cattle on family farms in southern Brazil
}

\author{
J. H. C. Costa, M. J. Hötzel, ${ }^{1}$ C. Longo, and L. F. Balcão \\ Laboratório de Etologia Aplicada e Bem-Estar Animal (LETA), Departamento de Zootecnia e Desenvolvimento Rural, \\ Universidade Federal de Santa Catarina, Rod. Admar Gonzaga, 1346 Itacorubi, 88034-001, Florianópolis, SC, Brazil
}

\begin{abstract}
A survey on dairy production in family dairy farms in the northwest of Santa Catarina, Brazil, was carried out to assess husbandry practices and elements of the living environment that may influence animal welfare and productivity. Three farm systems common in the region were compared: extensive, pasture-based, and semi-intensive. Data were collected through face-to-face interviews with farmers, followed by an inspection of the production environment and of dairy cows on 124 dairy farms. Some welfare and production problems were common to the 3 systems, mainly subclinical mastitis and tick infestations, which affected one-third of cows, deficiencies in the provision of drinking water and shade, and poor hygiene practices during milking. Some problems were specific to farming systems, such as lameness and hock injuries on the semi-intensive farms, and inadequate milking infrastructure and greater frequencies of cows with low body condition scores on extensive and pasture-based farms. A greater proportion of farms in the semi-intensive group had modern, herringbone-type milking parlors, applied the California Mastitis Test, and followed teat disinfection practices, and more pasture-based farms provided shade in the paddocks. The widespread use of pasture and adapted genotypes and individual identification of animals were positive aspects present in all systems. The absence of health and production records in more than half of the farms may prevent farmers from recognizing certain problems. Results of this survey may guide public policies aiming to improve milk productivity and quality with sustainable and low-cost production practices.
\end{abstract}

Key words: animal well-being, production system, stockmanship, farmer perception

Received July 4, 2012.

Accepted September 18, 2012.

${ }^{1}$ Corresponding author: mjhotzel@cca.ufsc.br

\section{INTRODUCTION}

Brazil is the fifth largest milk-producing country in the world, producing 30.7 billion liters per year (FAO, 2012). Santa Catarina, located in the southern part of the country (which also includes the states of Rio Grande do Sul and Paraná, between $22^{\circ} 32^{\prime} \mathrm{S}$ and $33^{\circ} 41^{\prime} \mathrm{S}$ ), is the fifth largest milk-producing state in Brazil (IBGE, 2009). Small family farms produce $80 \%$ of the milk in Brazil and $85 \%$ of the milk in the southern region, where the average herd size is estimated to be 24 cows (IBGE, 2009). In this paper, we use the term "family farm" as defined in the Item II of Article 4 of the Land Act, established by Law No. 4504 of November 30, 2004: "a farm that is directly and personally operated by the farmer and his family, to absorb their entire workforce, providing them with subsistence and social and economic progress, with a maximum area fixed for each region and type of operation, and occasionally worked with the help of others." In Santa Catarina, this area corresponds to up to 72 ha. In Santa Catarina, an overall herd of 933,000 dairy cows produces $2.13 \times 10^{9} \mathrm{~L}$, which represents $7.7 \%$ of Brazilian production (IBGE, 2009). To put these numbers in a global context, this amount of milk represents the equivalent of $13 \%$ of the milk production of New Zealand or $26 \%$ of that of Canada (FAO, 2012). Between 2005 and 2009, milk production in Santa Catarina increased, on average, by $9.5 \%$ per year (IBGE, 2009), which was explained by growth of the dairy herd and an increase in individual cow productivity (ICEPA, 2011). This growth has been pushed by government policies and extension programs aiming to modernize the dairy sector (Martinelli et al., 2010; Schneider and Niederle, 2010).

To gain and maintain access to competitive markets, the local industry will need to meet international quality standards. Together with "process attributes" such as traceability and safety aspects of the production system (Edwards, 2005) and environmental impact (Foley et al., 2011), animal welfare is increasingly becoming an issue in international policy and business operations. To direct the local industry, the Brazilian Ministry of Agriculture, Livestock and Food Supply established the 
"Permanent Technical Committee on Animal Welfare," which will propose standards and technical recommendations of good practice for animal welfare (Brasil, 2011). To support these standards, it is necessary to identify the major limitations to animal welfare in the different production systems and regions of Brazil. Surveys carried out in different countries have provided important insights into current dairy management practices used by farmers (Kehoe et al., 2007; Fulwider et al., 2008; Vasseur et al., 2010), which have helped guide producers, researchers, and other stakeholders interested in promoting farm animal welfare. Similar surveys of the production systems found in Brazil may help identify the main problems restricting productivity and welfare of dairy cattle, as well as potentials for good welfare, which can be used to guide researchers, extensionists, and policymakers to establish priorities.

On-farm assessment of animal welfare can be based on the evaluation of the provision of resources and management, direct observation of the animals, and examination of farm records (Whay et al., 2003). Whereas inspection of the environment may indicate the potential for certain welfare conditions, the assessment of the animals' health, body condition, and behavior can be used to infer the effects of housing and management on the welfare of these animals. Here, we report the results of a survey of dairy production on family dairy farms in the northwest of Santa Catarina, Brazil, considering 3 main farming systems of the region: extensive, pasturebased, and semi-intensive. The objectives were to assess the living environment and husbandry practices that may influence animal welfare and productivity; some aspects of the health, physical conditions, and behavior of cows; and the perceptions of the farmers regarding the main herd health problems.

\section{MATERIALS AND METHODS}

In total, 124 family farms distributed in $24 \mathrm{mu}-$ nicipalities in the northwest region of Santa Catarina, Brazil, participated in this study. Three main groups of farms - extensive, pasture-based, and semi-intensivewere considered, following the characterization described by Balcão et al. (2012) for farms in the region. In short, the extensive group presents the lowest production per unit of input, lack of any specific pasture management, no perennial forage species, no specific strategy of supplementation, and generally deficient facilities for milk production. The pasture-based group is based on intensive pasture production with rotational management and often uses fertilization; this group has a supplementation strategy defined according to the periods of greatest food scarcity, but prioritizes pasture as a source of livestock feed, thus keeping supplementation low. The semi-intensive group keeps cows on pasture during certain times of the day, but pasture is not the main source of feed; cows are housed indoors for a large proportion of the day, receiving silage and concentrate supplementation; feed is usually offered in a bunk alley with concrete flooring.

Extensionists, veterinarians, and agricultural technicians working for private or public extension bodies were asked to indicate 3 to 5 farms in total in their municipality, according to the production systems described here. Some farms were recruited using a snowball technique, whereby farmers who had agreed to participate were asked to recommend other farmers who would be willing to participate. Farmers were contacted directly by a member of the research team by telephone to make an appointment for a visit on a later occasion. Of all farmers approached, only 5 declined to participate.

Before the visit, the farmers were informed of the purpose of the study and were assured that their participation was voluntary and their identity would be kept confidential. The on-farm assessment took $0.5 \mathrm{~d}$ and included an hour-long interview and direct observation of the milking environment, milking routine, and dairy cows. Whenever available, production and health records were gathered from the farmer.

\section{Interviews}

Face-to-face interviews with the farmers were carried out using a questionnaire with multiple-choice and semi-closed questions to collect socioeconomic data and information regarding technical assistance, management, and husbandry practices. The first section of the interview covered data on the family, such as number, age, and education level of family members, number of years working in the dairy industry, and estimated percentage of income from dairy production, followed by farm characteristics such as pasture area, number of dairy cattle in each category (cows, heifers, and calves), and total milk production. In addition, questions were asked regarding frequency and type of extension and veterinary services received. The second part of the questionnaire referred to the management and husbandry practices used on the farm, with questions related to dry-off method (gradual or abrupt), location of veterinary procedures (milking parlor, feed bunk, or specific location), performance of California Mastitis Test (CMT; yes or no), most important disease (ticks, mastitis, tickborne diseases, reproductive problems, laminitis, calf diarrhea, or other), performance of postdipping (yes or no), recognition of all cows (yes or no), naming of cows (all, none, or some), and whether farmers believe that cows are able to feel pain (yes or 
no). At all times, farmers had the opportunity to clarify questions and add personal information and remarks.

\section{Inspection of the Environment}

The farm environment was inspected with the aid of a checklist to assess the provision of drinking water (present in some, all, or none of the paddocks; source: water trough or natural body) and shade (present in some, all, or none of the paddocks); the conditions of the grazing, milking, and waiting areas; and access to the milking parlor (good $=$ absence of rocks, mud puddles, or obstacles; regular $=$ presence of some rocks and mud puddles, absence of obstacles; bad = presence of rocks, mud puddles, and obstacles).

\section{Inspection of the Animals}

In total, 2,968 cows were inspected during the milking procedure to evaluate BCS, tick infestations, CMT score, and skin lesions on the legs and rump. Flight distance was assessed on 54 farms and gait score was assessed on 30 farms. The scoring protocols are described below.

$\boldsymbol{B C S}$. Animals were scored on a 5-point scale ranging from 1 (thin) to 5 (obese; Edmonson et al., 1989). Because only extreme BCS (too thin or too fat) is likely to have negative effects on animal welfare (Roche et al., 2009), cows were classified as BCS $\leq 2.0=$ thin, BCS $\geq 2.5$ and $\leq 4.0=$ ideal, and $\mathrm{BCS} \geq 4.5=$ obese.

Tick Infestations. Cows were scored during milking in the udder or groin and axilla, the major areas where ticks [Rhipicephalus (Boophilus) microplus] attack and therefore considered useful to assess infestations on dairy cows (L'Hostis et al., 1994). The score system used was as follows: score $0=$ no presence of ticks on the animal, and score $1=$ burden of ticks covering the skin. The percentage of cows per herd infested with ticks was calculated (\%).

$\boldsymbol{C M T}$. During the milking procedure, all cows were tested by CMT (Schalm and Noorlander, 1957) to identify mammary quarters with clinical or subclinical mastitis. The percentage of cows that presented at least one quarter positive by the $\mathrm{CMT}(\mathrm{CMT} \geq 1+)$ was calculated.

Skin Lesions. During milking, cows were inspected for leg lesions following the method proposed by Weary and Taszkun (2000) with some modifications: the areas around the tarsal joints (hocks) and rump were evaluated and scored as 0 (no hair loss and no swelling) or 1 (hairless patch, reddening, swelling of skin, or open wound), and the percentage of cows per herd that presented skin lesion in each area was calculated (\%).
Flight Distance. When weather and farm infrastructure permitted, the flight distance of milking cows was assessed, using the methodology used by Hötzel et al. (2005) in similar farming conditions. Briefly, 20 min after cows were taken to pasture after milking, one member of the team walked into the paddock where the cows remained; the tester started approximately $10 \mathrm{~m}$ away from the animal and, after being perceived by the animal, began walking slowly, perpendicular to the shoulder of the cow, with regular steps and with arms hanging straight down and held against the body. When the animal responded by moving away, the distance between the observer and the cow was measured. The same person carried out all tests. In total, 841 cows in 54 herds were tested.

Gait Scoring. When weather and farm infrastructure permitted, all cows were gait scored as they walked out of the exit of the parlor after milking. All cows were scored by a single, trained person. The scoring system used was an adaptation of the 5-point numerical rating system (NRS) proposed by Flower and Weary (2006), where $1=$ sound and $5=$ severely lame. Cows were considered "not lame" (score 0) when NRS $\leq 2.5$, and "lame" (score 1) when NRS $\geq 3$. In total, 623 cows in 30 herds were tested, and the percentage of lame cows per herd was calculated.

\section{Data Analysis}

Farm was considered the experimental unit in all analyses. Frequencies of farms were calculated for categorical (binary and nominal) variables generated using PROC FREQ in SAS 9.2 software (SAS Institute Inc., Cary, NC). Significance between production systems was tested by using the chi-squared test [Fisher's exact test was used only when there were fewer than 5 observations in a cell (in the contingency table)]. Descriptive statistics were calculated for continuous and ordinal variables using PROC NPAR1WAY, where medians and first and third quartiles (Q1, Q3) were calculated. The median one-way chi-squared test was used to compare the production systems.

\section{RESULTS}

\section{Socioeconomic and Herd Characteristics}

Socioeconomic data of each production system are reported in Tables 1 and 2. Groups did not differ for family size, age, number and education level of family members, or ethnic background (the self-reported ancestry was approximately $70 \%$ Italian, 20\% German, $5 \%$ other European, and 5\% "Brazilian"; $P>$ $0.2)$. 
Table 1. Socioeconomic and herd characteristics (medians with quartile 1-quartile 3 in parentheses) on extensive, pasture-based, and semiintensive dairy farms surveyed in Santa Catarina, Brazil ${ }^{1}$

\begin{tabular}{|c|c|c|c|c|c|}
\hline Variable & $\begin{array}{l}\text { Extensive } \\
(\mathrm{n}=23)\end{array}$ & $\begin{array}{l}\text { Pasture-based } \\
\quad(\mathrm{n}=50)\end{array}$ & $\begin{array}{l}\text { Semi-intensive } \\
\quad(\mathrm{n}=51)\end{array}$ & Total & $P$-value \\
\hline Family members $^{2}$ (no.) & $4.0(3.0-6.0)$ & $5.0(3.6-6.0)$ & $5.0(4.0-7.0)$ & $5.0(4.0-6.0)$ & 0.41 \\
\hline Age of father $(\mathrm{yr})$ & $47.0(44.5-50.0)$ & $47.0(39.0-52.0)$ & $50(42.5-55.0)$ & $47(41.3-53.0)$ & 0.35 \\
\hline Time in the dairy industry ${ }^{3}$ (yr) & $15.0(8.0-20.0)$ & $14.5(8.0-20.0)$ & $12(7.0-20.0)$ & $14(8.0-20.0)$ & 0.90 \\
\hline Total farm income from dairy ${ }^{4}(\%)$ & $70.0(50.0-93.8)$ & $60(50.0-80.0)$ & $72.5(50.0-93.8)$ & $70(50.0-93.8)$ & 0.38 \\
\hline Farm area (ha) & $21.8(13.0-28.0)$ & $20(12.0-39.8)$ & $37(27.8-76.9)$ & $27.3(14.4-45.0)$ & $<0.01$ \\
\hline Weaned heifers ${ }^{5}$ (no.) & $9.0(5.0-13.3)$ & $8.0(5.0-14.0)$ & $20.0(12.5-31.5)$ & $12.0(7.0-22.0)$ & $<0.01$ \\
\hline Calves $^{5}$ (no.) & $2.0(1.0-4.0)$ & $1.0(1.0-3.0)$ & $2.0(1.0-3.0)$ & $2.0(1.0-3.0)$ & 0.21 \\
\hline Total milk sold ${ }^{6}(\mathrm{~L} / \mathrm{d})$ & $157.5(81.3-300.0)$ & $125.0(100.0-190.0)$ & $460.0(330.0-850.0)$ & $235.0(110.0-450.0)$ & $<0.01$ \\
\hline
\end{tabular}

${ }^{1}$ Production systems were compared using the chi-squared test [Fisher's exact test was used only when fewer than 5 observations in a cell (the intersection between a column and a row in the contingency table)].

${ }^{2}$ Father, mother, children, and elders living at the farm.

${ }^{3}$ Selling milk to dairy company or cooperative on a regular basis.

${ }^{4}$ Farmer's estimate.

${ }^{5}$ Counted during the visit.

${ }^{6}$ Liters of milk delivered/day, according to last receipt from dairy company.

Pasture area, years in the dairy industry, and percentage of family income resulting from dairy production did not differ between groups; however, farms in the semi-intensive group presented greater farm area, more milking cows and heifers, and greater total milk production $(P<0.01)$ than farms in the 2 other groups (Table 1).

Ninety-six percent of farmers reported obtaining financial credit and $63 \%$ reported using it for infrastructure or other items of dairy production in the previous 2 yr; neither differed among farm groups $(P>0.5)$. More farmers of the semi-intensive group $(73 \%)$ hired labor compared with the other groups $(52 \%$ in the extensive group and $45 \%$ in the pasture-based group; $P=0.02$ ).

\section{Inspection of the Environment: Grazing Areas and Milking Parlor}

No difference was found among the farm groups regarding drinking water availability and source (Table
3). On most farms, shade was not available in paddocks, and many farmers reported moving the herd to a resting paddock with shade during the hottest hours of the day; the pasture-based group showed the greatest frequency of farms with access to shade in the paddocks $(P<0.05)$.

According to farmers' reports, cows had access to the pasture all year round on all farms, although differences were found between summer and winter months among groups $(P<0.01$; Table 4$)$.

All farms except 2 in the extensive group and 1 in the pasture-based group used machine milking, and all milked cows twice daily. The path leading from pasture to the milking parlor and the waiting area was rated "bad" in $22 \%$ of the farms, "regular" in $27 \%$, and "good" in $51 \%$ of the farms, with no group differences $(P>0.1)$. Nondairy animals were observed inside the milking parlor: dogs, cats, and poultry roamed in the milking parlor during milking, and livestock (pigs and, in some cases, poultry and sheep) were housed in the same building as the milking parlor (Table 4).

Table 2. Self-reported education level (\% of farms) of dairy farmers on extensive, pasture-based, and semi-intensive farms surveyed in Santa Catarina, Brazil

\begin{tabular}{|c|c|c|c|c|c|}
\hline Educational level & $\begin{array}{c}\text { Extensive } \\
(\mathrm{n}=23)\end{array}$ & $\begin{array}{l}\text { Pasture-based } \\
\quad(\mathrm{n}=50)\end{array}$ & $\begin{array}{l}\text { Semi-intensive } \\
\quad(\mathrm{n}=51)\end{array}$ & Total & $P$-value \\
\hline Formal education of father $(\mathrm{n}=124)$ & & & & & 0.33 \\
\hline Tertiary & 4 & 6 & 12 & 8 & \\
\hline Primary school (1 to 8 yr) & 61 & 81 & 70 & 73 & \\
\hline None & 9 & 2 & 2 & 3 & \\
\hline Formal education of mother $(\mathrm{n}=124)$ & & & & & 0.44 \\
\hline Primary school (1 to 8 yr) & 74 & 74 & 76 & 74 & \\
\hline
\end{tabular}


Table 3. Shade and drinking water made available to dairy cows on extensive, pasture-based, and semi-intensive dairy farms surveyed in Santa Catarina, Brazil

\begin{tabular}{|c|c|c|c|c|c|}
\hline Environmental variable & $\begin{array}{l}\text { Extensive } \\
(\mathrm{n}=23)\end{array}$ & $\begin{array}{c}\text { Pasture-based } \\
\quad(\mathrm{n}=50)\end{array}$ & $\begin{array}{l}\text { Semi-intensive } \\
\quad(\mathrm{n}=51)\end{array}$ & Total & $P$-value \\
\hline Drinking water & & & & & 0.21 \\
\hline Always & 39 & 54 & 37 & 44 & \\
\hline Water source & & & & & 0.77 \\
\hline Water trough & 52 & 64 & 63 & 61 & \\
\hline Natural water body & 22 & 22 & 20 & 21 & \\
\hline Never & 17 & 6 & 24 & 16 & \\
\hline Restricted & 74 & 69 & 69 & 69 & \\
\hline Always & 9 & 24 & 8 & 15 & \\
\hline
\end{tabular}

\section{Milking Management}

A person on foot moved cows between the paddocks and the milking parlor on $90 \%$ of the farms; on some farms this was done with the aid of a horse (4\%), motorcycle $(2 \%)$, or with dogs $(4 \%)$. Cows were tied by the legs or neck during milking in $87 \%$ of the extensive farms, $87 \%$ of the pasture-based farms, and $49 \%$ of the semi-intensive farms $(P<0.01)$. The frequency of farms where CMT and pre- and postdipping were performed is reported in Table 4 . Only $17 \%$ of the farmers declared imposing a specific milking order to prevent mastitis from spreading from contaminated to healthy cows, with no farm group difference $(P=0.32)$.

Table 4. Cattle genotype and management practices (\% of farms) reported by farmers of extensive, pasture-based, and semi-intensive dairy farms surveyed in Santa Catarina, Brazil

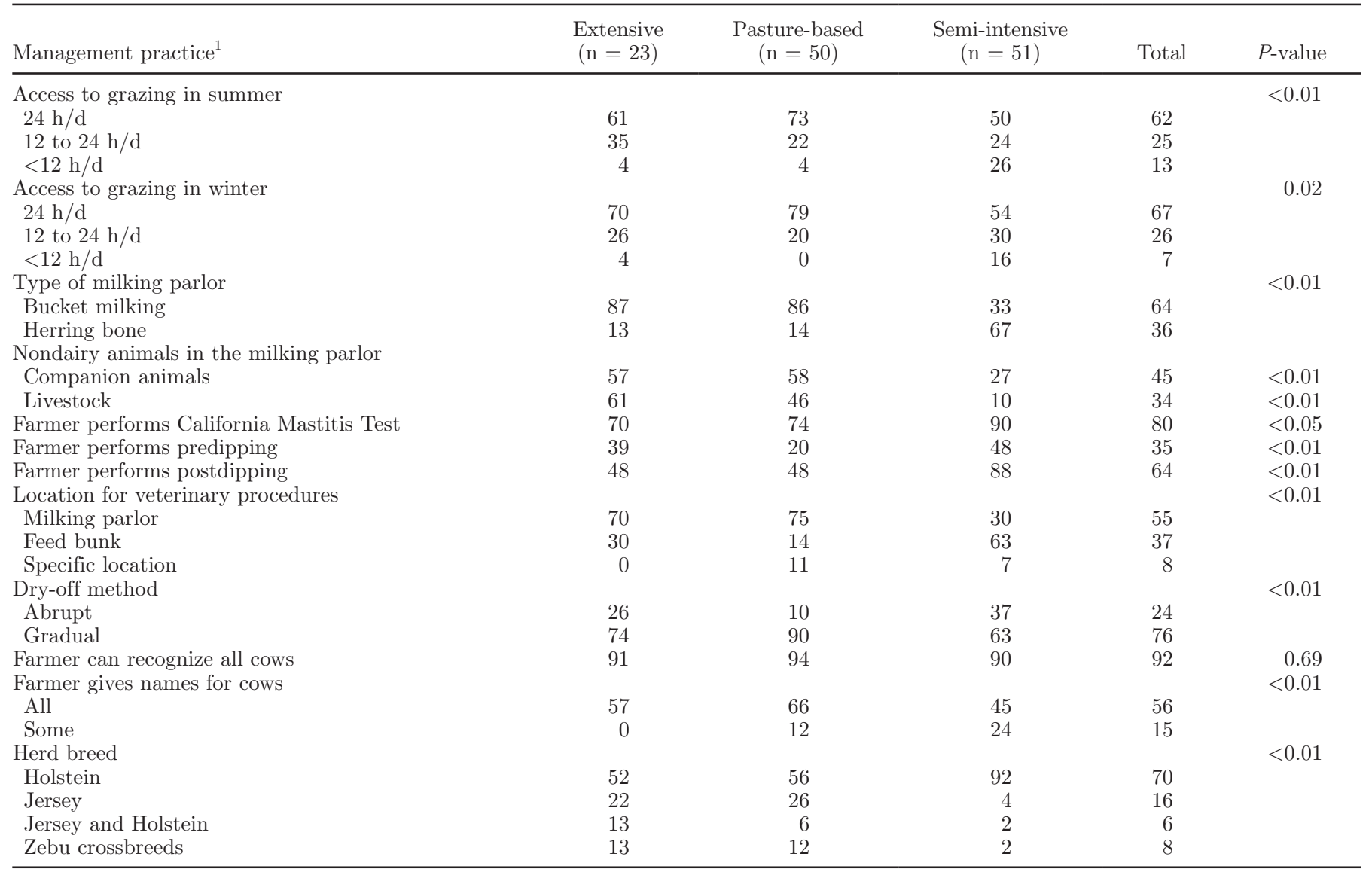




\section{General Practices}

Only $46 \%$ of the farmers kept production records ( $P$ $>0.8$ ). Specific facilities for veterinary purposes were found on only $8 \%$ of the farms. Farmers reported carrying out veterinary procedures such as vaccinations, clinical examinations, and administration of medications in the milking parlor or in the feed bunk, and this differed among farm groups $(P<0.01$; Table 4$)$.

Half of the farms did not have a specific location for calving, and $62 \%$ did not have any calving protocol or monitoring schedule for calving cows. Methods of drying cows at the end of lactation differed among farm groups $(P<0.01$; Table 4$)$. Artificial insemination was the exclusive method on $69 \%$ of the farms in the extensive group, on $84 \%$ of the farms in the pasture-based farms, and on $96 \%$ of the farms in the semi-intensive group $(P<0.01)$.

Over $90 \%$ of the farmers in all groups declared that they could recognize all individual dairy cows, and over half gave a name to each cow of the herd; this differed among groups $(P<0.01$; Table 4$)$. Most farmers (94\%) answered that cows are able feel pain, with no differences among groups $(P>0.96)$.

The predominant breed differed among groups $(P<$ 0.01 ; Table 4). The reasons offered for the choice of breed also differed $(P<0.01)$ : productivity was the reason given by $57 \%$ in the extensive and $39 \%$ in the pasture-based groups compared with $86 \%$ farmers in the semi-intensive group. Adaptability was the main reason given by $29 \%$ in the extensive and $41 \%$ in the pasture-based groups compared with $8 \%$ of the farmers in the semi-intensive group.

Farmers were asked to rate the diseases affecting their cows in order of importance. The most important diseases, according to farmers, were mastitis (56\%) and tickborne diseases (33\%), with other diseases mentioned by few farmers, including diarrhea in calves (4\%), reproductive diseases $(2 \%)$, and lameness $(2 \%)$. The main reasons reported for culling milking cows were reduced productivity (52\%), mastitis or "udder problems" (50\%), other health problems $(24 \%)$, reproductive problems $(22 \%)$, and renovation of the herd or aging $(24 \%)$. Responses did not differ among groups $(P$ $>0.1)$.

\section{Animal Inspection}

Flight distance of cows did not differ among groups $($ median $=2.79 \mathrm{~m}, \mathrm{Q} 1=2.37, \mathrm{Q} 3=3.22 ; P=0.5)$. The medians for the extensive ( $\mathrm{n}=10$ herds), pasturebased ( $\mathrm{n}=21$ herds), and semi-intensive ( $\mathrm{n}=23$ herds) groups were $2.42 \mathrm{~m}(\mathrm{Q} 1=2.40, \mathrm{Q} 3=3.04), 2.90(\mathrm{Q} 1=$ $2.34, \mathrm{Q} 3=3.35)$, and $2.96 \mathrm{~m}(\mathrm{Q} 1=2.33, \mathrm{Q} 3=3.08)$, respectively.

Median of lame cows per herd for the general population was 6.3 (Q1 = 0.0, Q3 = 18.2) and differed among the groups $(P<0.01)$. The semi-intensive group presented more lame cows $(\mathrm{n}=14$ herds, median $=17.4$, $\mathrm{Q} 1=7.7, \mathrm{Q} 3=22.2)$ than the pasture-based $(\mathrm{n}=$ 11 herds, median $=0.0, \mathrm{Q} 1=0.0, \mathrm{Q} 3=10.3$ ) and extensive $(\mathrm{n}=5$ herds, median $=5.0, \mathrm{Q} 1=4.2$, Q3 $=$ 5.6) groups.

Median BCS for the general population was 2.74 (Q1 $=2.60, \mathrm{Q} 3=2.87 ; P=0.8)$. The extensive group had a median BCS of $2.77(\mathrm{Q} 1=2.60, \mathrm{Q} 3=2.85)$, the pasture-based group had a median of $2.69(\mathrm{Q} 1=2.55$, $\mathrm{Q} 3=2.91$ ), and the semi-intensive group had a median $\mathrm{BCS}$ of $2.75(\mathrm{Q} 1=2.63, \mathrm{Q} 3=2.87)$. The frequency of thin cows per herd differed among the groups $(P<$ 0.01; Table 5).

Approximately one-third of the cows in each herd were infected by ticks and were positive by CMT (Table $5)$. Hock lesions and rump lesions differed among groups $(P<0.05$; Table 5).

\section{DISCUSSION}

This study is the first to provide information on the living environment and husbandry and management practices prevalent in 3 different dairy farm systems typical of Santa Catarina, Brazil. Overall, several positive and negative factors for animal welfare and milk production were identified that deserve attention of extensionists and policymakers involved in rural development and rural extension. The widespread ac-

Table 5. Frequency of occurrence (medians of cows/herd with quartile 1-quartile 3 in parentheses) of hock and rump lesions, thin and obese cows, tick infestation, and positive California Mastitis Test (CMT+) in dairy herds on extensive, pasture-based, and semi-intensive dairy farms surveyed in Santa Catarina, Brazil

\begin{tabular}{|c|c|c|c|c|c|}
\hline Variable & $\begin{array}{l}\text { Extensive } \\
(\mathrm{n}=23)\end{array}$ & $\begin{array}{c}\text { Pasture-based } \\
\quad(\mathrm{n}=50)\end{array}$ & $\begin{array}{l}\text { Semi-intensive } \\
\quad(\mathrm{n}=51)\end{array}$ & Total & $P$-value \\
\hline Thin cows & $10.1(0-22.2)$ & $11.1(0-19.4)$ & $0(0-8.7)$ & $4.6(0-14.6)$ & $<0.01$ \\
\hline Tick infestation & $38.9(11.1-57.2)$ & $31.2(10.3-70.0)$ & $16.6(2.3-47.8)$ & $27.8(5.9-57.1)$ & 0.13 \\
\hline Hock lesions & $2.4(0-11.8)$ & $6.3(0-11.1)$ & $13.3(5.1-30.2)$ & $7.8(0-17.2)$ & $<0.05$ \\
\hline Rump lesions & $2.1(0-14.3)$ & $0(0-3.4)$ & $3.3(0-6.3)$ & $0(0-6.2)$ & $<0.05$ \\
\hline
\end{tabular}


cess to pasture and the ability of farmers to recognize individual animals on most farms stood out as positive aspects for animal welfare. Among the negative aspects identified, we highlight deficiencies in the supply of drinking water and shade in outdoor areas, inadequate milking management and hygiene, a high prevalence of cows with mastitis and ticks, cows with low BCS in farms that rely on pasture as the main source of food, and lame cows on farms that make high use of concentrates.

\section{Use of Pasture}

The use of pasture was perhaps the most widespread positive management aspect for cow welfare. In most of the farms surveyed, cows spent more than $12 \mathrm{~h} / \mathrm{d}$ on pasture, in accordance with reports that milk production in the region is largely based on grazing systems (ICEPA, 2011). Even the semi-intensive group, which relied on concentrates as the main source of food, made relatively high use of pasture. In general, access to pasture improves the welfare of dairy cattle because it provides a natural environment where cows can express behaviors such as grazing and exploring (Krohn, 1994) and can exercise, which may be beneficial for their health (Regula et al., 2004). In addition, lying time increases when cows are housed on pasture compared with tie stalls (Krohn and Munksgaard, 1993); thus, pasture is considered a more comfortable lying surface for dairy cows than those found in confined housing. However, complex interactions between weather, previous experience with pasture, and energy requirements and supply influence the time high-producing cows choose to spend on pasture or indoors (Legrand et al., 2009; Charlton et al., 2011; Falk et al., 2012). These interactions, which are not yet fully understood, need to be studied in subtropical climates such as in southern Brazil, where different genotypes and diets predominate.

The fact that between 12 and $14 \%$ of the cows per herd in the pasture-based and extensive groups had low BCS suggests low pasture quality and availability in some farms. Low food quality and availability is a prominent concern in pasture-based production systems, especially when low or no supplementation is offered to compensate for fluctuations in pasture supply. Besides reducing cows' productivity, 2 important welfare concerns are hunger and the increased risk of health problems during lactation in cows with very low BCS (Roche et al., 2008). Better pasture management and strategic supplementary feeding are necessary to overcome this problem. To guide this recommendation, the quality and abundance of feed during the year, along with their relationships with the animal's body condition and health, need to be analyzed in further detail. This would require several visits to analyze critical periods of forage abundance and the quality of feed offered to the animals. Pasture management must be considered a priority for pasture-based dairy production systems, given its importance for productivity and animal welfare, and its implications for the quality of water and soil, and greenhouse gas emissions (Steinfeld et al., 2006).

\section{Provision of Water and Shade}

Restricted or insufficient provision of drinking water and shade in outdoor areas were common features of most farms visited. Shade was not provided on many farms in this study, although it is known that dairy cows have a strong motivation to seek shade to avoid the heat and sunlight during hot weather (Schütz et al., 2008). Many farmers reported mitigating the absence of shade in the paddocks where cows grazed by moving the herd to shaded paddocks in the hottest periods of days they considered hot. However, because this strategy depends on farmers' judgment and availability for the task, cows may often be exposed to thermal stress. Rump lesions suggest effects of excessive exposure to sun, as these were more prevalent in the semi-intensive and extensive groups, the groups with the least access to shade in outdoor areas. Importantly, thermal stress is also likely to reduce milk production (West, 2003), but the lack of production records on farms may limit farmers' awareness of the problem.

Suboptimal water consumption decreases animal performance markedly faster than any other nutrient and, if combined with thermal stress, it can severely compromise the welfare of the animals (Armstrong, 1994). Dairy cows consume more water when it is available ad libitum, in contrast to when it is only offered during milking (Hötzel et al., 2003), which was the case in many farms on this survey. Other factors were identified in the survey that are known to reduce the water consumption in dairy cows: supply in natural ponds instead of water troughs (Bica, 2005), troughs of inadequate size (Machado Filho et al., 2004; Teixeira et al., 2006), and water being located in corridors leading to the paddocks instead of inside the paddocks (Coimbra et al., 2012).

The pasture-based group tended to have better water and shade supply than the other groups, which reflects the adoption of agroecological dairy production practices introduced by extensionists in the region in the last 2 decades (Canaver et al., 2006). Several factors, such as farmer's attitudes, cultural practices, and 
economical standings may influence their decisions to make the necessary investments and changes to supply water and shade. These factors need to be understood to guide extension programs aimed at improving this problem of dairy cows that spend several hours per day on pasture.

\section{Herd Health: Tick Infestations, Mastitis, and Lameness}

An important aspect of animal health in southern Brazil is the high prevalence of ectoparasites, including ticks, and the diseases that they transmit (Grisi et al., 2002). Approximately $30 \%$ of the cows in this study were infested by ticks. This was not different among the groups of farms, which is consistent with the use of pasture on all farms, where the parasites can complete their cycle. Ticks cause skin irritations and anemia (Sangwan et al., 1995), which reduce welfare, and they are vectors of Babesia, Theileria, and Anaplasma spp. (Dreyer et al., 1998), which cause diseases with a high risk of mortality in animals. Management and strategies to control ticks and effective extension programs are needed to mitigate this relevant health and welfare problem. The main difficulties for improvements are resistance to acaricides, the presence of chemical residues in milk associated with treatments, and the effective use of control strategies (George et al., 2004). For instance, do Amaral et al. (2011) identified the poor understanding of tick biology among farmers in another region of Brazil as being a critical limitation to the appropriate application of control strategies.

Mastitis incidence was high in all groups, with around one-third of the cows in each herd testing positive by CMT. Absence of premilking teat-end wash and postmilking teat dip was identified in another study (Oliveira et al., 2011) in a different region of Brazil, and was considered a potential risk factor for aerobic mesophilic bacteria contamination in the milk. Although the semi-intensive group stood out positively in some aspects of milking practices, such as more frequent use of postdipping and CMT, more modern milking parlors, and less presence of animals other than cows within the milking parlor, these factors were not associated with better udder health. This indicates the need for specific studies to better understand the predisposing causes of mastitis in the different systems. For example, the influence of the microbiological quality of water should be assessed, because a recent study showed that water is contaminated in many farms in the region (João et al., 2011). This survey highlights the need for significant environmental, management, and husbandry changes for farmers to comply with current Brazilian legislation dictating hygiene practices and milk quality standards (Brasil, 2011).

Lameness rates were relatively high in the farms of the semi-intensive group, in which cows produced more milk, received a large proportion of their feed as silage and grains, and spent a large proportion of the day indoors. The lower levels of lameness in the pasture-based and extensive groups may have been a result of the high use of pasture (Hernandez-Mendo et al., 2007), the use of genotypes adapted to the environment, and low levels of supplementation and lower milk production (Baird et al., 2009). Lameness is one of the main welfare and production issues in dairy (Whay et al., 2003; Rushen et al., 2008), because it increases the risk of premature culling (Sprecher et al., 1997) and can result in reduced milk yield (Green et al., 2002), cause pain (Whay et al., 1998), and reduce fertility (Sprecher et al., 1997; Hernandez et al., 2001). The causes of lameness in cows in the region need to be investigated, considering that all herds have access to pasture for several hours per day, which is expected to reduce the incidence of the disease (Hernandez-Mendo et al., 2007). Possible predisposing causes are the rocky paths and wet and muddy waiting areas found on many farms. This may also explain lameness in some cows in the extensive and pasturebased groups. Furthermore, lameness rates in herds in the region need to be more accurately estimated on a larger number of farms, which requires the development and validation of assessment methods suitable for the conditions on these types of farms.

Farmers cited mastitis and tickborne diseases as the 2 main herd health problems, and udder problems as the most important reason for culling cows, which is in accordance with the high prevalence of both diseases among the herds. In contrast, they underestimated the prevalence of lameness in their herds, as reported elsewhere (Whay et al., 2003). One possible reason for this difference is that it may be relatively more difficult for farmers to perceive lameness in their cows than to detect mastitis or tick infestations, which have more overt signs. Furthermore, influenced by professional advisers and by companies that sell veterinary drugs (da Silva et al., 2012), farmers may be aware of the clinical signs and economic importance of ticks and mastitis, 2 highly prevalent conditions in the region, but not of lameness, which is largely associated with confined systems. An important issue identified in this survey was the lack of records, which may prevent farmers from accurately assessing the prevalence of the different diseases in their herds. To improve awareness of herd health problems, which is essential for the success of prevention programs, further studies are necessary to understand the knowledge and attitudes of farmers and extensionists toward diseases. 


\section{Practices and Habits Associated with the Quality of the Human-Animal Relationship}

Some management practices considered negative for dairy cow welfare stood out in the survey, especially in farms of the pasture-based and extensive groups: the use of the milking parlor to carry out veterinary treatments, the habit of tying cows during milking, and the presence of livestock and companion animals within the milking parlor. Cows may perceive some animals as predators, which can cause stress and avoidance behavior responses in cows (Welp et al., 2004). Avoiding associations between painful or aversive treatments with the location where milking is carried out forms the basis for the recommendation to allocate a specific location for veterinary procedures (Rushen et al., 2008; Hötzel et al., 2009). Stressful situations surrounding milking can lead to avoidance behaviors (Rushen et al., 2001; Hötzel et al., 2005) and reduce milk production (Silanikove, 2000; Rushen et al., 2001), mainly due to the increase in residual milk (Rushen et al., 2001), which is an important risk factor for the development of mastitis (Dohoo and Meek, 1982). However, in contrast with these practices, average flight distances found in this study suggest overall positive or neutral human-animal relationships. This may be explained by some positive routine management practices, which may involve interactions with positive reinforcing outcomes, such as milking and moving cows between the milking parlor and pasture. Additionally, the generalized practice of offering concentrate during milking may counteract the expected negative effect of aversive experiences in the milking parlor on the cow's behavior (Hötzel et al., 2009).

Most farmers surveyed were able to recognize all dairy cows in their herds and perceived cows as capable of feeling pain. Altogether, about 70\% of farmers gave names to all or some cows in the herd. In a further study, farmers in the region offered 3 complementary explanations for their habit of calling cows by name: the practical need to refer to them and call them during management, cultural habit, and the expression of their emotional proximity to the cows (Cardoso et al., 2012). Bertenshaw and Rowlinson (2009) found a positive association between receiving a name, milk production, and behavior of dairy cows. Positive welfare outcomes may arise from cows being recognized as individuals and belonging to small herds; for example, it may lead to individual care and attention and early identification of signs of disease.

\section{CONCLUSIONS}

This study identified several specific limitations and potentials for improved productivity and animal welfare of 3 distinct groups of dairy farmers in Santa Catarina, Brazil. These differences highlight the need to recognize the specificities of different dairy farming systems when designing and implementing public policies and extension programs. To ensure that the growth of the dairy industry in the region follows a sustainable path, policymakers, extensionists, and research agencies should consider the following priorities: (1) help farmers make changes in infrastructure and practices to comply with Brazilian legislation regarding milk quality and milking standards; (2) promote the adoption of efficient grazing systems for dairy production and improvements in pasture management and in the supply of shade and drinking water; and (3) control widespread herd health problems that reduce economic efficiency and animal welfare in dairy cows, especially mastitis, tick infestations, and lameness. Moreover, to support the success of these initiatives, further understanding is needed of the perceptions and knowledge of farmers and extensionists regarding several of the issues studied here, such as disease prevalence and management, pasture and feeding management, and cow behavior and welfare.

\section{ACKNOWLEDGMENTS}

We thank the farmers, the local extensionists who participated in this study, and Clarissa Cardoso, Francieli Bertoli, Rolnei Ruã Dáros (Universidade Federal de Santa Catarina, Florianópolis, SC, Brazil), and Tracy Anne Burnett (visiting student from the University of British Columbia, Vancouver, BC, Canada). This project was funded by the $\mathrm{MCT} / \mathrm{CNPq} / \mathrm{CT}$-Agronegócio/ MAPA-SDC 40/2008, Proc. 505862/2008-5, and MEC/ CAPES 029/2010, Proc. 23038.006958/2010-62. M. J. Hötzel was funded by CNPq, PQ-308919/2009-2.

\section{REFERENCES}

Armstrong, D. V. 1994. Heat stress interaction with shade and cooling. J. Dairy Sci. 77:2044-2050.

Baird, L. G., N. E. O'Connell, M. A. McCoy, T. W. J. Keady, and D. J. Kilpatrick. 2009. Effects of breed and production system on lameness parameters in dairy cattle. J. Dairy Sci. 92:2174-2182.

Balcão, L. F., C. Longo, J. H. Cardoso Costa, R. R. Dáros, C. S. Cardoso, and M. J. Hötzel. 2012. Dairy systems in the northwest of Santa Catarina: Typology by cluster analysis. In Anais da 49 Reunião da Sociedade Brasileira de Zootecnia, Brasilia, DF, Brazil.

Bertenshaw, C., and P. Rowlinson. 2009. Exploring stock managers' perceptions of the human-animal relationship on dairy farms and an association with milk production. Anthrozoos 22:59-69.

Bica, G. S. 2005. Bebedouro: Bem-estar animal e proteção ambiental no suprimento de água para bovinos de corte. MS Thesis. Federal University of Santa Catarina, Florianópolis, Brazil.

Brasil. 2011. Ministério da Agricultura, Pecuária e Abastecimento. Portaria $n^{0}$ 524, de junho de 2011. Normativa $n^{\circ} 62$ de 29 de dezembro de 2011. Regulamento Técnico de Produção, Identidade e Qualidade do Leite Tipo A, do Leite Tipo B, do Leite Tipo C, do Leite pasteurizado e do Leite Cru Refrigerado e o Regulamento 
Técnico da Coleta de Leite Cru Refrigerado e seu Transporte a Granel. Diário Oficial da União, Brasília, DF, Brazil.

Canaver, B. S., A. B. Reck, D. Enríquez, and L. C. P. Machado Filho. 2006. Produção agroeocológica de leite em pastoreio racional voisin em municípios do oeste catarinense. Extensio 4:1-9.

Cardoso, C. S., C. U. Gómez, and M. J. Hötzel. 2012. Decision-making of family farmers in Santa Catarina regarding husbandry practices that influence the welfare of dairy cattle. In Anais da 49 Reunião da Sociedade Brasileira de Zootecnia, Brasilia, DF, Brazil.

Charlton, G. L., S. M. Rutter, M. East, and L. A. Sinclair. 2011. Preference of dairy cows: Indoor cubicle housing with access to a total mixed ration vs. access to pasture. Appl. Anim. Behav. Sci. 130:1-9.

Coimbra, P. A. D., L. C. P. Machado Filho, and M. J. Hötzel. 2012 Effects of social dominance, water trough location and shade availability on drinking behaviour of cows on pasture. Appl. Anim. Behav. Sci. 139:175-182.

da Silva, T. P. P., J. C. Moreira, and F. Peres. 2012. Are tick medications pesticides? Implications for health and risk perception for workers in the dairy cattle sector. Cien. Saude Colet. 17:311-325.

do Amaral, M. A. Z., C. M. B. M. Rocha, J. L. Faccini, J. Furlong, C. M. O. Monteiro, and M. C. A. Prata. 2011. Perceptions and attitudes among milk producers in Minas Gerais regarding cattle tick biology and control. Rev. Bras. Parasitol. Vet. 20:194-201.

Dohoo, I. R., and A. H. Meek. 1982. Somatic cell counts in bovine milk. Can. Vet. J. 23:119-125.

Dreyer, K., L. J. Fourie, and D. J. Jok. 1998. Epidemiology of tickborne diseases of cattle in Botshabelo and Thaba Nchu in the Free State Province. Onderstepoort J. Vet. Res. 65:285-289.

Edmonson, A. J., I. J. Lean, L. D. Weaver, T. Farver, and G. Webster. 1989. A body condition scoring chart for Holstein dairy cows. J. Dairy Sci. 72:68-78

Edwards, S. A. 2005. Product quality attributes associated with outdoor pig production. Livest. Prod. Sci. 94:5-14.

Falk, A. C., D. M. Weary, C. Winckler, and M. A. G. von Keyserlingk. 2012. Preference for pasture versus freestall housing by dairy cattle when stall availability indoors is reduced. J. Dairy Sci. 95:64096415.http://dx.doi.org/10.3168/jds.2011-5208.

FAO. 2012. Agriculture Data: FAOSTAT. Accessed Mar. 12, 2012. http://faostat.fao.org/site/573/default.aspx\#ancor.

Flower, F. C., and D. M. Weary. 2006. Effect of hoof pathologies on subjective assessments of dairy cow gait. J. Dairy Sci. 89:139-146.

Foley, J. A., N. Ramankutty, K. A. Brauman, E. S. Cassidy, J. S Gerber, M. Johnston, N. D. Mueller, C. O'Connell, D. K. Ray, P. C. West, C. Balzer, E. M. Bennett, S. R. Carpenter, J. Hill, C. Monfreda, S. Polasky, J. Rockström, J. Sheehan, S. Siebert, D. Tilman, and D. P. M. Zaks. 2011. Solutions for a cultivated planet. Nature 478:337-342.

Fulwider, W. K., T. Grandin, B. E. Rollin, T. E. Engle, N. L. Dalsted, and W. D. Lamm. 2008. Survey of dairy management practices on one hundred thirteen north central and northeastern United States dairies. J. Dairy Sci. 91:1686-1692.

George, J. E., J. M. Pound, and R. B. Davey. 2004. Chemical control of ticks on cattle and the resistance of these parasites to acaricides. Parasitology 129:353-366.

Green, L. E., V. J. Hedges, Y. H. Schukken, R. W. Blowey, and A. J. Packington. 2002. The impact of clinical lameness on the milk yield of dairy cows. J. Dairy Sci. 85:2250-2256.

Grisi, L., C. L. Massard, G. E. Moya-Borja, and J. B. Pereira. 2002 Impacto das principais ectoparasitoses em bovinos no Brasil. Hora Vet. 21:8-10

Hernandez, J., J. K. Shearer, and D. W. Webb. 2001. Effect of lameness on the calving-to-conception interval in dairy cows. J. Am. Vet. Med. Assoc. 218:1611-1614.

Hernandez-Mendo, O., M. A. G. von Keyserlingk, D. M. Veira, and D. M. Weary. 2007. Effects of pasture versus freestall housing on lameness in dairy cows. J. Dairy Sci. 90:1209-1214.

Hötzel, M. J., C. C. M. Gomes, and L. C. P. Machado Filho. 2009. Behaviour of dairy cows subjected to aversive conditioning. Biotemas $33: 135-140$.
Hötzel, M. J., L. C. P. Machado Filho, D. L. Teixeira, F. M. Wolf P. A. D. Coimbra, M. C. Yunes, P. S. L. Dinon, and E. J. C. Lopes. 2003. Effects of physiological state on water consumption of water-restricted dairy cows. Pages 237-241 in Proc. 9th World Conf. Anim. Prod., Porto Alegre, Brazil. Gráfica UFRGS, Porto Alegre, Brazil.

Hötzel, M. J., L. C. P. Machado Filho, M. C. Yunes, and M. C. A. Silveira. 2005. An aversive milker causes fear, but does not influence milk yield of Holstein cows. R. Bras. Zootec. 34:1278-1284.

IBGE. 2009. Censo Agropecuário. Accessed Sep. 6, 2011. http://www. ibge.gov.br/home/estatistica/economia/agropecuaria/censoagro/.

ICEPA. 2011. Síntese Anual da Agricultura de Santa Catarina 2010/2011. Accessed Jan. 2012. http://cepa.epagri.sc.gov.br/.

João, J. H., C. André, L. Rosa, A. T. Neto, C. A. Picinin, J. J. Fuck, and G. Marin. 2011. Water quality used in milking parlors of dairy farms in midwest of Santa Catarina State, Brazil. Rev. Cienc. Agrovet. 10:9-15.

Kehoe, S. I., B. M. Jayarao, and A. J. Heinrichs. 2007. A survey of bovine colostrum composition and colostrum management practices on Pennsylvania dairy farms. J. Dairy Sci. 90:4108-4116.

Krohn, C. C. 1994. Behaviour of dairy cows kept in extensive (loose housing/pasture) or intensive (tie stall) environments: III. Grooming, exploration, and abnormal behaviour. Appl. Anim. Behav. Sci. $42: 73-86$.

Krohn, C. C., and L. Munksgaard. 1993. Behaviour of dairy cows kept in extensive (loose housing/pasture) or intensive (tie stall) environments: II. Lying and lying down behaviour. Appl. Anim. Behav. Sci. 37:1-16.

Legrand, A. L., M. A. G. von Keyserlingk, and D. M. Weary. 2009 Preference and usage of pasture versus free-stall housing by lactating dairy cattle. J. Dairy Sci. 92:3651-3658.

L'Hostis, M., O. Diarra, and H. Seegers. 1994. Sites of attachment and density assessment of female Ixodes richrus (Acari: Ixodidae) on dairy cows. Exp. Appl. Acarol. 18:681-689.

Machado Filho, L. C. P., D. L. Teixeira, D. M. Weary, M. A. G. von Keyserlingk, and M. J. Hötzel. 2004. Designing better water troughs: Dairy cows prefer and drink more from larger troughs. Appl. Anim. Behav. Sci. 89:185-193.

Martinelli, L. A., R. Naylor, P. M. Vitousek, and P. Moutinho. 2010 Agriculture in Brazil: Impacts, costs, and opportunities for a sustainable future. Curr. Opin. Environ. Sustainability 2:431-438.

Oliveira, C. J. B., W. D. Lopes Junior, R. C. R. E. Queiroga, P. E. N. Givisiez, P. S. Azevedo, W. E. Pereira, and W. A. Gebreyes. 2011. Risk factors associated with selected indicators of milk quality in semiarid northeastern Brazil. J. Dairy Sci. 94:3166-3175.

Regula, G., B. Danuser, B. Spycher, and B. Wechler. 2004. Health and welfare of dairy cows in different husbandry systems in Switzerland. Prev. Vet. Med. 66:247-264.

Roche, J. R., D. Blache, J. K. Kay, D. R. Miller, A. J. Sheahan, and D. W. Miller. 2008. Neuroendocrine and physiological regulation of intake, with particular reference to domesticated ruminant animals. Nutr. Res. Rev. 21:207-234.

Roche, J. R., N. C. Friggens, J. K. Kay, M. W. Fisher, K. J. Stafford, and D. P. Berry. 2009. Invited review: Body condition score and its association with dairy cow productivity, health, and welfare. J. Dairy Sci. 92:5769-5801.

Rushen, J., A. M. B. de Passillé, M. A. G. von Keyserlingk, and D. M. Weary. 2008. The Welfare of Cattle. 5th ed. Springer, Dordrecht, the Netherlands.

Rushen, J., L. Munksgaard, P. G. Marnet, and A. M. de Passillé. 2001. Human contact and the effects of acute stress cows at milking. Appl. Anim. Behav. Sci. 73:1-14.

Sangwan, A. K. M. B. Chhabra, and S. S. Chaudbri. 1995. Status report on ticks and mites affecting domestic livestock in Haryana. Agric. Rev. Karnal 16:117-127.

Schalm, O. W., and D. D. Noorlander. 1957. Experiments and observations leading to development of the California Mastitis Test. J. Am. Vet. Med. Assoc. 130:199-204.

Schneider, S., and P. A. Niederle. 2010. Resistance strategies and diversification of rural livelihoods: The construction of autonomy among Brazilian family farmers. J. Peasant Stud. 37:379-405. 
Schütz, K. E., N. R. Cox, and L. R. Matthews. 2008. How important is shade to dairy cattle? Choice between shade or lying following different levels of lying deprivation. Appl. Anim. Behav. Sci. 114:307-318

Silanikove, N. 2000. Effects of heat stress on the welfare of extensively managed domestic ruminants. Livest. Prod. Sci. 67:1-18.

Sprecher, D. J., D. E. Hostetler, and J. B. Kaneene. 1997. A lameness scoring system that uses posture and gait to predict dairy cattle reproductive performance. Theriogenology 47:1179-1187.

Steinfeld, H., P. Gerber, T. Wassenaar, V. Castel, M. Rosales, and C. de Haan. 2006. Livestock's Long Shadow: Environmental Issues and Options. Food and Agriculture Organization of the United Nations (FAO). FAO, Rome, Italy.

Teixeira, D., M. J. Hötzel, and L. C. P. Machado Filho. 2006. Designing better water troughs: 2 . Surface area and height, but not depth, influence dairy cows' preference. Appl. Anim. Behav. Sci. 96:169-175.

Vasseur, E., F. Borderas, R. I. Cue, D. Lefebvre, D. Pellerin, J. Rushen, K. M. Wade, and A. M. de Passillé. 2010. A survey of dairy calf management practices in Canada that affect animal welfare. J. Dairy Sci. 93:1307-1315.

Weary, D. M., and I. Taszkun. 2000. Hock lesions and free-stall design. J. Dairy Sci. 83:697-702.

Welp, T., J. Rushen, D. L. Kramer, M. Festa-Bianchet, and A. M. de Passillé. 2004. Vigilance as a measure of fear in dairy cattle. Appl. Anim. Behav. Sci. 87:1-13.

West, J. W. 2003. Effects of heat-stress on production in dairy cattle. J. Dairy Sci. 86:2131-2144.

Whay, H. R., D. C. Main, L. E. Green, and A. J. Webster. 2003. Assessment of the welfare of dairy cattle using animal-based measurements: Direct observations and investigation of farm records. Vet. Rec. 153:197-202.

Whay, H. R., A. E. Waterman, A. J. F. Webster, and J. K. O'Brien. 1998. The influence of lesion type on the duration of hyperalgesia associated with hind limb lameness in dairy cattle. Vet. J. $56: 23-29$. 